\title{
Perbandingan Kejadian Infeksi Saluran Kemih setelah Pemasangan Kateter antara 24-36 Jam dan 36-48 Jam pada Pasien Pascaoperasi Ginekologi
}

\author{
Windy Puspa Kusumah, Benny Hasan Purwara, Eppy Darmadi Achmad \\ Departemen Obstetri dan Ginekologi Fakultas Kedokteran Universitas Padjadjaran \\ Rumah Sakit Dr. Hasan Sadikin Bandung \\ Korespondensi: Windy Puspa Kusuma, Email: windipuspa@gmail.com
}

\begin{abstract}
Abstrak
Tujuan:Penggunaan kateter pada saat dilakukan operasi merupakan prosedur rutin termasuk operasi ginekologi sehingga kandung kemih tetap kosong pada saat operasi serta mencegah jejas.

Metode: Penelitian analitik komparatif dibagi menjadi 2 kelompok, pelepasan 24-36 jam dan 36-48 jam. Hasil dipstik leukosit diambil pre-operasi dan 24-36 jam dan 36-48 jam pasca-operasi.

Hasil: Total terdapat 48 pasien dengan umur antara 31-40 tahun 29.2\% serta umur 41-50 tahun 29.2\%. Lama operasi antara 1 sampai 2 jam sebanyak 54.2\%. Kelompok 36-48 jam, hasil leukosit urine terbanyak $(+)$ ada 62.5\%. Pemasangan Kateter 24-36 jam yang awalnya (-) kelompok 36-48 jam menjadi (+) sebanyak 60.0\%. Diskusi:Penelitian ini mengikutsertakan 63 subjek yang memenuhi kriteria inklusi sebanyak 48 orang yang dibagi menjadi dua kelompok. Pasien pascaoperasi dengan peningkatan leukosit urine ditemukan pada $57 \%$ subjek di kelompok pelepasan kateter 36-48 jam pasca operasi, sedangkan hanya $15 \%$ pada kelompok pelepasan kateter 24-36 jam pasca operasi.

Kesimpulan: Pelepasan kateter pascaoperasi 36-48 jam, lebih banyak terjadi insidensi peningkatan leukosit urine dibandingkan kelompok 24-36 jam.
\end{abstract}

Kata kunci: Infeksi saluran kemih, kateter pra-operasi, kateter pasca-operasi

\section{Comparison of Urinary Tract Infections after the Insertion of Catheter between 24-36 Hours and 36-48 Hours on Post Gynecologic Surgery Patients}

\begin{abstract}
Objective: Use of catheter during surgery is a routine procedure in every surgery, also gynecological surgery so the bladder remains empty during surgery. Catheter may prevent iatrogenic injury of the bladder caused by overdistention and atony due to anesthesia.

Method: Unpaired categorical comparative analytic study with subjects were categorized into 2 groups, groups of patients in 24-36 hours catheters and patients in 36-48 hours post-surgery catheters. Urine leukocyte dipstick taken pre-surgery, 24-36 hours and 36-48 hours post-surgery.

Result: A total of 48 patients were selected for data use for this study. For the longest operation time between 1 to 2 hours as much as 54.2\%. For 24-36 hours urine leukocyte with negative results as much as $75 \%$. While in the 36-48 hours catheter insertion there were 62.5\%. Increasing of urine leukocyte result at 24-36 hours catheter insertion in 36-48 hours catheter insertion group.

Discussion: The study included 63 subjects divided into two groups. Post-surgery patients with elevated urinary leukocytes were found in 57\% of subjects in the 36-48 hours post-surgery catheter release group, while only 15\% in the 24-36 hours catheter release group.

Conclusion: Post-surgery catheters 36-48 hours, there was a greater incidence of urinary leukocyte increment than the group of patients with 24-36 hours post-surgery catheters.
\end{abstract}

Keywords: Urinary tract infection, pre-surgery catheter, post-surgery catheter. 


\section{Pendahuluan}

Penggunaan kateter pada saat dilakukan operasi merupakan prosedur rutin pada setiap operasi, salah satunya pada operasi ginekologi sehingga kandung kemih tetap kosong pada saat operasi. Penggunaan kateter pada saat operasi dapat mempermudah saat pelaksanaan operasi serta mencegah jejas iatrogenik pada kandung kemih yang disebabkan karena distensi berlebih dan atoni karena pengaruh anestesi. ${ }^{1}$ Kateter juga berguna dalam menilai pengeluaran urin serta memastikan warna urin yang keluar normal. ${ }^{1}$

Setelah operasi kateter urin tidak dilepaskan untuk mencegah retensi urin pasca-operasi yang dapat menyebabkan atonia kandung kemih dan meningkatkan morbiditas pada proses urinasi seperti kesulitan menahan kencing, ketidakstabilan pada detrusor, dan meningkatkan risiko infeksi saluran kemih. ${ }^{2}$ Namun, pemasangan kateter dalam waktu lama akan meningkatkan koloni bakteri dan menyebabkan infeksi pada saluran kemih sehingga hal tersebut dapat menyebabkan morbiditas pada pasien serta memperpanjang waktu rawat di rumah sakit yang berdampak pada peningkatan dalam segi biaya untuk perawatan. ${ }^{3}$

Panduan prosedur dan strategi penggunaan kateter sangat diperlukan agar dapat mencegah terjadinya infeksi saluran kemih serta bakteriuria asimptomatik. Waktu yang tepat untuk pelepasan kateter pascaoperasi masih diperbincangkan dan dilakukan berdasarkan kebiasaan bukan berdasarkan bukti ilmiah. Penelitian menyatakan bahwa terdapat hubungan antara pemasangan kateter dengan kejadian infeksi saluran kemih. ${ }^{4}$ Kemudian penelitian lain menyatakan bahwa pelepasan kateter urin pada 24 jam pasca-operasi berhubungan dengan insidensi infeksi saluran kemih dibandingkan dengan pelepasan kateter pada 0 jam dan 6 jam pasca operasi. ${ }^{5}$ Liang berpendapat bahwa angka kejadian infeksi saluran kemih tertinggi terjadi pada hari kedua pada kelompok yang menggunakan kateter. $^{6}$ Namun, berbeda dengan penelitian lain yang menyatakan bahwa tidak ada perbedaan pada kejadian infeksi saluran kemih pada hari ke-1 dan ke3. ${ }^{7}$

Berdasarkan latar belakang tersebut peneliti ingin mengetahui perbandingan kejadian infeksi saluran kemih pada penggunaan kateter pada 24-36 dan 36-48 jam pasca-operasi ginekologi.

\section{Metode}

Penelitian ini merupakan suatu penelitian analitik komparatif. Penelitian dilakukan di RS dr. Hasan Sadikin Bandung mulai 16 April 2017 sampai 15 Mei 2017. Sampel penelitian adalah semua pasien yang dilakukan pemasangan kateter pasca-operasi ginekologi di RS dr. Hasan Sadikin Bandung dalam periode 16 April 2017 sampai $15 \mathrm{Mei}$ 2017. Data untuk penelitian ini didapatkan dari hasil dipstick leukosit urine pasien pre dan pasca-operasi ginekologi setelah pemasangan kateter 24-36 jam dan 36-48 jam dalam periode 16 April 2017 sampai $15 \mathrm{Mei}$ 2017.

Kriteria inklusi pada penelitian ini, semua pasien yang dilakukan operasi ginekologi dengan dipstick urin pre-operasi negatif. Kriteria eksklusi pada penelitian ini, semua pasien yang dilakukan operasi ginekologi dengan dipstick urin pre-operasi + atau ++ , dan pasien menolak mengikuti penelitian

\section{Hasil}

Data yang diperoleh kemudian disusun dan ditabulasi serta disajikan dalam bentuk tabel dan naratif . Pemasangan kateter selama 2436 jam untuk hasil (-) sebanyak 15 orang atau sebesar $62.5 \%$ dan $(+)$ sebanyak 9 orang atau sebesar 37.5\%. Untuk Pemasangan Kateter selama 36-48 jam dimana untuk hasil (-) 
sebanyak 5 orang atau sebesar $20.8 \%$, untuk $(+)$ sebanyak 15 orang atau sebesar $62.5 \%$ dan hasil $(++)$ sebanyak 4 orang atau sebesar $16.7 \%$. Terdapat perbedaan signifikan atau bermakna secara statistik. Dengan demikian dapat dijelaskan bahwa terdapat perbedaan signifikan secara statistik antara variabel pemasangan kelompok pemasangan kateter 24-36 jam dibandingkan dengan kelompok 36-48 jam. Hasil analisis statistik berikut ini:

\section{Tabel 1 Karakteristik Subjek Penelitian}

\begin{tabular}{ll}
\hline \multicolumn{1}{c}{ Variabel } & $\mathbf{N}=\mathbf{4 8}$ \\
\hline Umur & \\
Rerata (SB) & $40.9(12.6)$ \\
Lama Operasi & \\
<4 Jam & $43(79.2 \%)$ \\
>4 Jam & $5(20.8 \%)$ \\
\hline
\end{tabular}

Tabel 2 Hasil Leukosit Urine dengan Kelompok Pemasangan Kateter 24-36 jam dan Kelompok Pemasangan Kateter 36-48 jam.

\begin{tabular}{|c|c|c|c|}
\hline \multirow[t]{2}{*}{ Variabel } & \multicolumn{2}{|c|}{$\begin{array}{c}\text { Kelompok Pasang } \\
\text { Kateter }\end{array}$} & \multirow{2}{*}{$\begin{array}{c}\text { Nilai } \\
\text { p* }^{*}\end{array}$} \\
\hline & 24-36 jam & 36-48 jam & \\
\hline $\begin{array}{c}\text { Hasil Leukosit } \\
\text { Urine }\end{array}$ & & & 0.01 \\
\hline$(-)$ & $15(62.5 \%)$ & $5(20.8 \%)$ & \\
\hline+ & $9(37.5 \%)$ & $15(62.5 \%)$ & \\
\hline++ & 0 & $4(16.7 \%)$ & \\
\hline
\end{tabular}

*Uji Chi Square
Total terdapat 48 pasien yang dipilih untuk dipakai datanya bagi penelitian ini. Karakteristik subjek keseluruhan pasien penelitian menurut umur dengan rata-rata sebesar $40.937 \pm 12.547$. Lama operasi terbanyak kurang dari 4 jam sebanyak 43 orang atau sebesar $79.2 \%$

\section{Pembahasan}

Hasil penelitian dalam periode 16 April 2017 sampai 15 Mei 2017 terdapat 63 pasien yang dilakukan pemasangan kateter pasca-operasi ginekologi di Rumah Sakit dr. Hasan Sadikin Bandung. Total terdapat 48 pasien yang dipilih untuk dipakai datanya bagi penelitian ini.

Data pada Tabel 1 menjelaskan karakteristik subjek keseluruhan pasien penelitian menurut Umur dan Lama Operasi. Untuk umur dengan rata-rata sebesar 40.937 \pm 12.547 . Untuk Lama Operasi terbanyak dibawah atau sama dengan 4 jam sebanyak 43 orang atau sebesar 79.2\%. Hal ini tidak berhubungan dengan kejadian infeksi saluran kemih.

Data pada Tabel 2 menjelaskan hasil Pemasangan Kateter 24-36 jam pada kelompok hasil leukosit urine (-) sebesar $62,5 \%$. Pada kelompok hasil leukosit urin $(+)$ sebesar $37.5 \%$ dan pada kelompok hasil leukosit urine $(++)$ tidak ada sama sekali. Dan pada hasil Pemasangan Kateter 3648 jam pada kelompok hasil leukosit urine (-) sebanyak 5 orang atau sebesar 20,8\%.

Tabel 3 Hasil Pemasangan Kateter 24-36 jam dan Pemasangan Kateter 36-48 jam dengan kelompok Leukosit Urine

\begin{tabular}{|c|c|c|c|c|}
\hline \multirow{2}{*}{ Variabel } & \multicolumn{3}{|c|}{$\begin{array}{c}\text { Kelompok Hasil Leukosit } \\
\text { Urine }\end{array}$} & \multirow{2}{*}{ Nilai p* $^{*}$} \\
\hline & $\begin{array}{c}(-) \\
N=20\end{array}$ & $\begin{array}{c}(+) \\
N=24\end{array}$ & $\begin{array}{l}(++) \\
N=4\end{array}$ & \\
\hline Pasang Kateter & & & & 0.01 \\
\hline 24-36 jam & $15(75 \%)$ & $9(37.5 \%)$ & 0 & \\
\hline 36-48 jam & $5(25 \%)$ & $15(62.5 \%)$ & $4(100 \%)$ & \\
\hline
\end{tabular}

*Uji Chi Square 
Pada kelompok hasil leukosit urine (+) sebanyak 15 orang atau sebesar $62.5 \%$ dan pada kelompok hasil leukosit urine $(++)$ sebanyak 4 orang atau sebesar 16,7\%. Hal ini memperkuat penelitian sebelumnya yang menyatakan bahwa angka kejadian infeksi saluran kemih tertinggi terjadi pada hari kedua pada kelompok yang menggunakan kateter. $^{4-6}$

Data pada Tabel 3 menjelaskan hasil leukosit urine (-) pada pemasangan Kateter 24-36 jam sebesar 75\% dan pada pemasangan Kateter 36-48 jam sebesar 25\%. Untuk hasil leukosit urine $(+)$ pada pemasangan Kateter 24-36 jam sebesar 37.5\% dan pada pemasangan Kateter 36-48 jam sebesar $62.5 \%$. Sedangkan untuk hasil leukosit urine $(++)$ pada pemasangan Kateter 24-36 jam tidak ada sama sekali dan pada pemasangan Kateter 36-48 jam sebesar 100\%. Hal ini juga memperkuat penelitian sebelumnya yang menyatakan bahwa angka kejadian infeksi saluran kemih tertinggi terjadi pada hari kedua pada kelompok yang menggunakan kateter. $^{4-6}$

Keterbatasan pada penelitian ini yaitu faktor subjektivitas dalam menentukan leukosit urine pada dipstick, karena ditentukan berdasarkan kualitas, bukan kuantitas. Untuk saran, sebaiknya hasil leukosit urine dikonfirmasi secara kuantitatif di laboratorium. Simpulan pada kelompok pasien dengan pemasangan kateter 36-48 jam, terdapat peningkatan angka kejadian kenaikan leukosit urine dibandingkan pada kelompok pemasangan kateter 24-36 jam pasca-operasi.

\section{Daftar Pustaka}

1. Ghoreishi J. Indwelling urinary catheters in cesarean delivery. Int J Gynecol Obstet. 2003;83:267-70.

2. Chai J, Pun T. A prospective randomized trial to compare immediate and 24-hour delayed catheter removal following total abdominal hysterectomy. Acta Obstet Gynecol Scand. 2011;90:478-82.

3. Ahmed MR, Ahmed WAS, Atwa KA, Metwally L. Timing of urinary catheter removal after uncomplicated total abdominal hysterectomy: a prospective randomized trial. Eur J Obstet Gynecol Reprod Biol. 2014;176:60-3.

4. Samad RA. Hubungan pemasangan kateter dengan kejadian infeksi saluran kemih pada pasien di ruang rawat inap penyakit dalam RSUDZA Banda Aceh tahun 2012. Jurnal Keperawatan Medikal Bedah. 2013;1(1).

5. Magdy, Ahmed R. Timing of urinary catheter removal after uncomplicated total abdominal hysterectomy: a prospective randomized trial. Eur J Obstet Gynecol Reprod Biol. 2014;176:60-3.

6. Liang C-C, Lee C-L, Chang T-C, Chang Y-L, Wang C-J, Soong Y-K. Postoperative urinary outcomes in catheterized and non-catheterized patients undergoing laparoscopic-assisted vaginal hysterectomy - a randomized controlled trial. Int Urogynec. 2009;20(3):295-300.

7. Vahr S, Cobussen-Boekhorst H, Eikenboom J, Geng V, Holroyd S, Lester $\mathrm{M}$, et al. Evidence-based Guidelines for Best Practice in Urological Health Care: Catheterisation: Urethral intermittent in adults, Dilation, urethral intermittent in adults. Arnhem, Netherlands: European Association of Urology Nurses; 2013. ISBN 978-90-79754-59-5; 2015. 